\title{
Market Participation and Economic Capital
}

\begin{abstract}
The market economy supports human wellbeing. This chapter offers evidence for this observation, while recognising that markets need rules, customs and institutions to work well. A key market institution is the firm, which combines different types of capital to maintain specialist capabilities for supplying goods and services valued by their customers. This expands the potential for wellbeing, but a large number of jobs pay less than the real living wage, with a strong gender bias, which diminishes wellbeing. The chapter analyses economic capital, comprised of physical capital and financial capital. Growth in economic capital has increased material living standards for billions of people, but recent economic development is also associated with cumulative environmental damage, episodes of financial instability and greater concentration of wealth.
\end{abstract}

Keywords Economic capital $\bullet$ Market strength $\bullet$ Capability theory of the firm - Unemployment $\bullet$ Living wage

To lead valued lives, people must access goods and services for meeting basic needs, and then for pursuing other goals (Maslow 1943, 1954). There are moral limits to the use of markets for this purpose (Sandel 2012), and the following two chapters will analyse other important cases of market failure. Nevertheless, goods and services necessary for wellbeing are often supplied by firms that 
operate in markets for inputs and outputs. Participation in the market economy therefore enhances capabilities for wellbeing beyond what persons could achieve through social networks alone.

The chapter begins by analysing four features of competitive markets that make this possible: specialised production, rewards for creating new value, decentralised decision-making and Pareto efficient outcomes. The potential is not always realised, however, and so the chapter also pays attention to how markets need well-designed rules, customs and institutions to work well.

The chapter then analyses a key institution in every market economy: the firm. Firms develop specialised capabilities for supplying valued goods and services, and provide access to the market economy by offering people opportunities for paid employment. Both roles support wellbeing.

Economic capital is a term used to cover physical capital (such as buildings and machinery) and financial capital (such as shares and bonds). Growth in these assets can promote wellbeing, but with important policy issues analysed in the third section of the chapter. The Global Financial Crisis in 2007-2008, for example, had a sharp impact on physical capital investment and exposed vulnerabilities in the global architecture for financial capital (Crotty 2009). Piketty (2013) has documented how capital accumulation can concentrate financial wealth and increase economic inequality.

The chapter finishes with a brief summary. It accepts the potential of the market economy and of economic capital for expanding the capabilities of persons to lead valued lives, but argues there is more to understand about how to harness the benefits of these institutions for wellbeing.

\section{Markets and Wellbeing}

John McMillan (2002) showed how markets have emerged in human history wherever there were enough people for their operation and no political or military forces acting to suppress them. This is itself evidence that markets can be useful for wellbeing, but McMillan recognises a crucial caveat (idem, pp. 13-14):

Markets, then, are the most potent antipoverty engine there is - but only where they work well. The caveat is crucial. ... Left to themselves, markets can fail. To deliver their full benefits, they need support from a set of rules, customs, and institutions. They cannot operate efficiently in a vacuum. 
Based on that insight, Proposition 13 recognises the potential of markets for contributing to enhanced wellbeing, while acknowledging that achievement of this potential requires a well-designed institutional structure.

Proposition 13 Persons can enhance wellbeing by participating as sellers and as buyers in the market economy; but markets need rules, customs and institutions to work well.

This does not mean all possible market transactions are morally or socially acceptable. Human trafficking and exploitative child labour, for example, are universally rejected, as codified in international agreements such as the 2003 Protocol to Prevent, Suppress and Punish Trafficking in Persons, especially Women and Children and the 1990 Convention on the Rights of the Child. There is also a strong public consensus that access to life-changing services such as housing, education and health should not be restricted by a person's low market income.

Within limits such as these, four features help explain the potential of markets for contributing to enhanced wellbeing. First, a key insight in Smith's (1776) Wealth of Nations was its recognition that a market economy allows producers to specialise in their range of outputs and in their production. This is feasible because producers can rely on markets to buy inputs and sell outputs. Smith's opening chapter introduced this feature using the example of pins manufacture (Smith 1776, Volume 1, p. 8):

One man draws out the wire, another straightens it, a third cuts it, a fourth points it, a fifth grinds it at the top for receiving the head; to make the head requires two or three distinct operations; to put it on is a peculiar business, to whiten the pins is another; it is even a trade by itself to put them into the paper; and the important business of making a pin is, in this manner, divided into about eighteen distinct operations...

Smith estimated that in his time, ten workers could make upwards of 48,000 pins a day, whereas not more than 200 were possible without this division of labour. Thus, specialisation can greatly increase the productivity of workers (measured as the value of their output per hour of work), which is an important driver of higher material living standards. ${ }^{1}$

Second, the market economy rewards successful developments of new ways to deliver value to consumers. This was explained by Joseph Schumpeter (1943) 
in his influential book Capitalism, Socialism and Democracy. Emphasising benefits from the "creative destruction" of capitalism, Schumpeter explained how market dynamism is driven by the innovation of entrepreneurs (idem, p. 83):

The fundamental impulse that sets and keeps the capitalist engine in motion comes from the new consumers' goods, the new methods of production or transportation, the new markets, the new forms of industrial organization that capitalist enterprise creates.

Third, the market supports decentralised decision-making that is able to respond to economic shocks such as discoveries of new technologies or changes in consumer preferences. In competitive markets, these shocks result in relative price adjustments, which cause producers and consumers to shift resources to where they have become more highly valued, in a way that no central planner could hope to achieve. This feature was emphasised by Friedrich Hayek (1945, p. 520):

The marvel is that in a case like that of a scarcity of one raw material, without an order being issued, without more than perhaps a handful of people knowing the cause, tens of thousands of people whose identity could not be ascertained by months of investigation, are made to use the material or its products more sparingly; i.e., they move in the right direction.

Fourth, the First Fundamental Theorem of Welfare Economics, introduced by economists including Nobel Laureates Ken Arrow (1951) and Gérard Debreu (1959), demonstrates that a system of perfectly competitive markets, involving private goods with no externalities (so that private costs equal social costs), produces an outcome where no one's preference satisfaction can be increased without reducing the satisfaction of someone else. This property is termed Pareto efficiency (Pareto 1906; Hicks 1939). It prevails because the price in a competitive market equals the cost to society of producing one more unit of the traded item (its marginal cost) and equals the amount consumers are willing to pay for that extra unit (its marginal benefit).

Thus, a consumer choosing to pay the market price of an item is forced to recognise the marginal benefit of that item to other consumers and the marginal cost of supplying a replacement. Similarly, producers are forced to recognise in their decision-making the marginal costs of other producers and the marginal benefits to all consumers. 
These features make competitive markets a potentially powerful mechanism for supplying goods and services needed to enhance wellbeing. Specialisation allows greater value to be delivered to diverse customers. Firms pay the marginal cost of each input and create outputs for which consumers are willing to pay more than the total cost of their production. There are incentives for successful innovation. The economic outcome is efficient in the sense that no one's preferences can be further satisfied without diminishing the satisfaction of someone else.

This potential is not always realised for all consumers. Market outcomes depend on the distribution of resources among households. This is because purchasing power is the principal factor determining access to market goods and services, and so resources flow towards high-wealth households, while low-wealth persons are vulnerable to exploitation by those holding greater market power. Consequently, it is reasonable for citizens to be concerned about poverty and income inequality in the market economy (Rawls 1971; Sen 2009) and for public policy to be designed so that all persons can access housing, health and education services independently of their household income (see Chap. 7).

Further, markets often fail to meet the strict requirements for the theories of perfect competition to apply. Market transactions may involve externalities or the traded item may be an economic public good (see Chaps. 6 and 7). There may be only one seller (monopoly) or one buyer (monopsony). If there are few buyers or sellers, the market may produce outcomes considered unjust without countervailing power on the other side (Galbraith 1952). Sellers may use customer loyalty to take advantage of an inefficient market structure known as monopolistic competition (Robinson 1933; Chamberlin 1933). Consumers may be unable to judge the quality of a potential purchase, unsure whether to trust supplier claims about product safety or professional expertise (Darby and Karni 1973; Caswell and Mojduszka 1996).

Hence, there is room for good public policy to restrict anti-competitive behaviour in established markets. The UK regulatory regime for promoting competition, for example, has four main elements (Seely 2016, p. 12): investigating markets that might be working poorly for consumers; controlling mergers that might be anti-competitive; enforcing prohibitions against anti-competitive business agreements, price fixing and other abuses of market strength; and generally advocating for the benefits of competition. The emergence of new technologies supporting on-line markets has created new challenges for competition policy (see the analysis of Google, Facebook, Amazon and eBay by Haucap and Heimeshoff 2013). 


\section{Firms and Capabilities}

Firms are a key institution in any market economy. At the beginning of 2016, there were 5.5 million private sector businesses in the United Kingdom (Rhodes 2016, p. 5). Of these, 4.2 million were operated by sole proprietors with no employees. This section focuses on the other 1.3 million private sector businesses with at least one employee, which we call firms. The vast majority of firms employed fewer than ten people, but 40 per cent of total employment in all firms was accounted for by 7000 large businesses with at least 250 employees (ibid).

An important question posed initially by Ronald Coase (1937, p. 390) is "why a firm emerges at all in a specialised exchange economy". Given the strengths of market transactions discussed in the previous section, why are any economic activities managed within firms, rather than all persons being selfemployed and all transactions being organised through markets?

Coase's insight was that market trades have their own transaction costs, including the cost of time needed to discover relevant market prices, negotiate separate contracts, and make allowances for contingencies and risks. Under some circumstances, these transaction costs are avoided "when the direction of resources is dependent on an entrepreneur" within a firm (idem, p. 393).

Coase's explanation has been developed further, including by Nobel Laureates Oliver Williamson (2010) and Oliver Hart (2017). This research has highlighted other factors giving rise to firms. A firm is better able to invest in assets specifically designed for its chosen outputs, for example, and a firm might reduce the unit costs of production as the scale of its activity increases.

Building on that tradition, David Teece (1982) has created a capability theory of the firm. ${ }^{2}$ This conceptualises a firm as an ongoing institution that sustains two types of capabilities: operational capabilities, necessary for supplying to market the firm's chosen outputs; and dynamic capabilities, driving entrepreneurial innovation within the firm (see also Teece et al. 1997). Dynamic capabilities are the more important, reflecting the crucial function of senior management to identify and exploit opportunities (Teece 2017a, p. 698):

For applied purposes, dynamic capabilities can usefully be broken down into three primary clusters of activities: (1) identification, development, co-development and assessment of technological opportunities in relationship to customer needs (sensing); (2) mobilization of resources to address needs and opportunities, and to capture value from doing so (seizing); and (3) continued renewal (transforming). 
The emphasis on technology opportunities in relationship to customer needs is consistent with this book's understanding of knowledge capital as an essential input into production systems (see Chap. 7). Knowledge capital includes intellectual property, customer relationship management systems and other intangible assets based on specialised knowledge. This form of capital is particularly valuable because "knowledge, capabilities and other intangibles are not only scarce; they are often difficult to imitate" (Teece 2017a, p. 699).

All capital types considered in this book are important for a market firm. Consider a high street retail business. It leases a fitted-out store (economic capital) and employs skilled staff (human capital). It develops internal norms for daily operations (cultural capital) and maintains good relations with other businesses and people (social capital). It operates a sophisticated customer relationship management system and protects a distinctive brand (knowledge capital). Its logistics, energy and waste disposal systems use environmental resources (natural capital). Its supply chain relies on contracts and trusted relationships with partners around the globe (diplomatic capital).

Combining these capitals allows a firm to build its capability for quality goods and services that customers come to understand and trust. Proposition 14 therefore draws on the capability theory of the firm to provide a definition that fits the wellbeing economics framework.

Proposition 14 Firms operating in the market economy can combine different types of capital to maintain specialist capabilities for supplying goods and services valued by their customers.

Throughout history, some firms have damaged wellbeing, including through large-scale dispossession of indigenous peoples during the global expansion of the market system in the nineteenth century (Polanyi 1944). As discussed earlier in this book, current activities of firms continue to cause environmental damage (Jackson 2017), although there are also consumer-led movements aiming to reward firms that demonstrate social and environmental responsibility ( $\mathrm{PwC}$ 2013; GRI 2016). ${ }^{3}$ Proposition 14 also indicates why the market economy favours households with high wealth. Customer values are expressed in the market economy by willingness-to-pay, so that low-wealth households have weak purchasing power to access goods and services produced by firms, even if those goods and services would greatly increase their wellbeing.

Nevertheless, the capability theory also explains how firms can improve human wellbeing. Proposition 2 states that wellbeing can be enhanced by 
expanding the capabilities of persons to lead the kinds of lives they value. Proposition 14 states that firms operating in the market economy maintain specialist capabilities. Thus, firms can expand opportunities for wellbeing by increasing capabilities, at least for those who can find employment in firms or otherwise have the financial means to purchase the goods and services that firms provide.

Drawing on this discussion, Fig. 5.1 presents a model of Proposition 14, depicting a firm's capabilities as the result of integrating different types of capital. This is designed to complement the skills model in Fig. 2.2 of Chap. 2 (both diagrams feature in the final chapter). Knowledge capital is highlighted because of its centrality in the dynamic capabilities of a firm. Human capital is highlighted because it is embodied in the firm's staff and so is central to the employment opportunities offered in the enterprise.

Employment is the primary means by which persons earn market income to purchase goods and services that contribute to the kind of life they value. It also offers social connections and may contribute to a person's social identity. It is not surprising, therefore, that one of the strongest findings in the wellbeing literature is that unemployed people generally report lower values for happiness and life satisfaction than do employed people, influenced by a range of personal and social factors. ${ }^{4}$

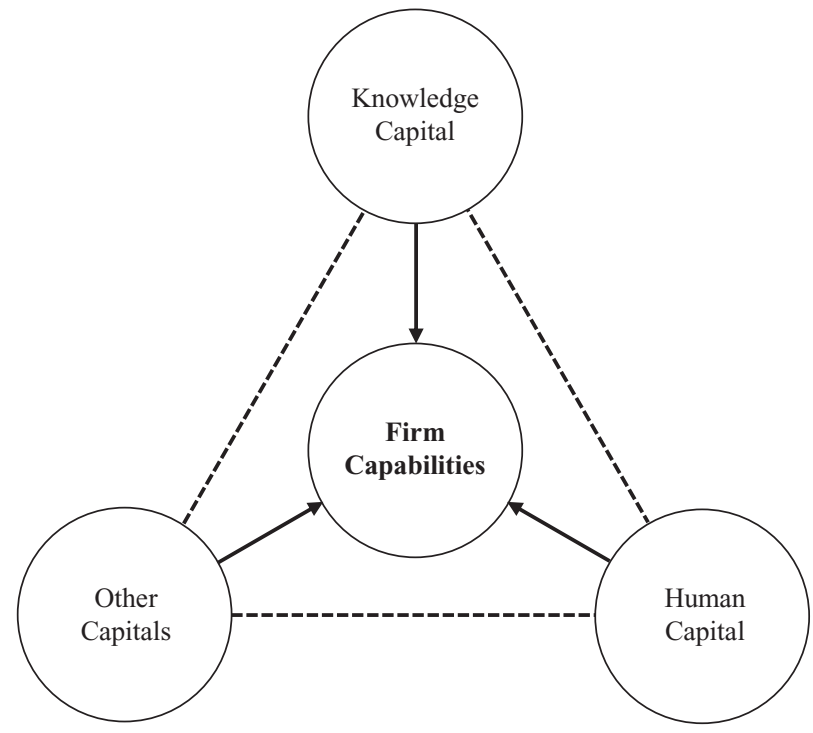

Fig. 5.1 Firm capabilities as the integration of human, knowledge and other capitals 
Winkelmann (2014) observes that reduced life satisfaction upon becoming unemployed is associated with a sense of departing from accepted social norms towards paid work. Hence, the impact tends to be smaller when a greater number of local people also have no job (Clark 2003). The loss of subjective wellbeing is more than can be explained by lost earnings. Psychological damage comes from factors such as lost economic identity, a sense of personal failure, feelings of insecurity, and reduced self-confidence in the ability to determine personal outcomes (Winkelmann 2014, p. 8).

Further, the need to focus on urgent problems caused by unemployment "captures the mind", which can lead to poor decision-making that neglects other sources of wellbeing (Shah et al. 2012; Mullainathan and Shafir 2013). Unemployment leaves scarring effects such as lower future wages (Gregory and Jukes 2001; Arulampalam 2001), higher risks of further spells of unemployment (Gregg 2001) and lower subjective wellbeing even when re-employed (Clark et al. 2001). Wellbeing reported by those who are not unemployed is also lower when there is higher unemployment among peers (Clark 2003; De Neve and Ward 2017, p. 154).

Employment is therefore important for wellbeing, but quality of employment should not be overlooked since "insecure and poor quality employment is also associated with increased risks of poor physical and mental health" (Marmot 2010 , p. 26). De Neve and Ward (2017) report that blue-collar jobs and lowincome jobs are associated with lower levels of subjective wellbeing, while other evidence shows strong connections between job quality and wellbeing (idem, p. 145$)^{5}$ :

Work-life balance emerges as a particularly strong predictor of people's happiness. Further factors include job variety and the need to learn new things, as well the level of individual autonomy enjoyed by the employee. Moreover, job security and social capital (as measured through the support one receives from fellow workers) are also positively correlated with happiness, while jobs that involve risks to health and safety are generally associated with lower levels of subjective wellbeing.

A critical consideration is income earned in a job. It may be reasonable for entry-level jobs employing school-leavers to offer lower wages while a young person builds relevant experience, but older people who may have family responsibilities require decent wages (taking into account income support through social security policies; see Chap. 7 ) to lead lives they have reason to value by the standards of their peers. 
Table 5.1 Statutory national minimum wage, statutory national living wage, and voluntary or real living wage, United Kingdom, April 2017

\begin{tabular}{ll}
\hline Age Band & Rate Per Hour \\
\hline Statutory National Minimum Wage & \\
Under 18 & $f 4.05$ \\
$18-20$ & $f 5.60$ \\
$20-24$ & $f 7.05$ \\
Statutory National Living Wage & \\
25 and over & $£ 7.50$ \\
Voluntary or real living wage & $£ 9.75$ in London \\
18 and over & $£ 8.45$ in rest of United Kingdom \\
\end{tabular}

Note: These figures exclude Apprentice Rates

Sources: https://www.gov.uk/national-minimum-wage-rates and https://www.livingwage. org.uk/what-real-living-wage

In the United Kingdom, this difference is recognised in a distinction between minimum wages and living wages. Table 5.1 shows the statutory national minimum wage and the statutory national living wage, plus a third category that is referenced as either the voluntary living wage (IHS Markit 2017) or the real living wage (Living Wage Foundation 2017).

The principle behind the voluntary or real living wage is "that work should bring dignity and should pay enough to provide families the essentials of life" (Hirsch and Moore 2011, p. 4). Its calculation is therefore based on actual living costs, which are higher in London than elsewhere in the United Kingdom, taking into account income support received through social security. In April 2017, the voluntary real living wage was estimated to be $£ 9.75$ per hour in London and $£ 8.45$ in the rest of the country.

Table 5.1 shows that the statutory rates in the United Kingdom increase with the employee's age, reaching $£ 7.50$ per hour at 25 years. Even this highest rate is well below the voluntary or real living wage, however, so that the minimum wage that employers must pay by statute is less than the rate considered sufficient to provide families with the essentials of life.

IHS Markit is commissioned annually by KPMG to analyse jobs paying less than the voluntary living wage. The analysis for 2017 estimated that 5.5 million people aged 18 or older were employed on these terms. Where the employee was aged between 18 and 21, two-thirds of the jobs paid below the voluntary living wage (see Fig. 5.2). One-quarter of jobs did not meet the threshold where employees were aged 22 to 29. Even for employees in their 30s, 40s and 50s, the percentage of jobs not paying the voluntary living wage was $15-16$ per cent (IHS Markit 2017, p. 11). 


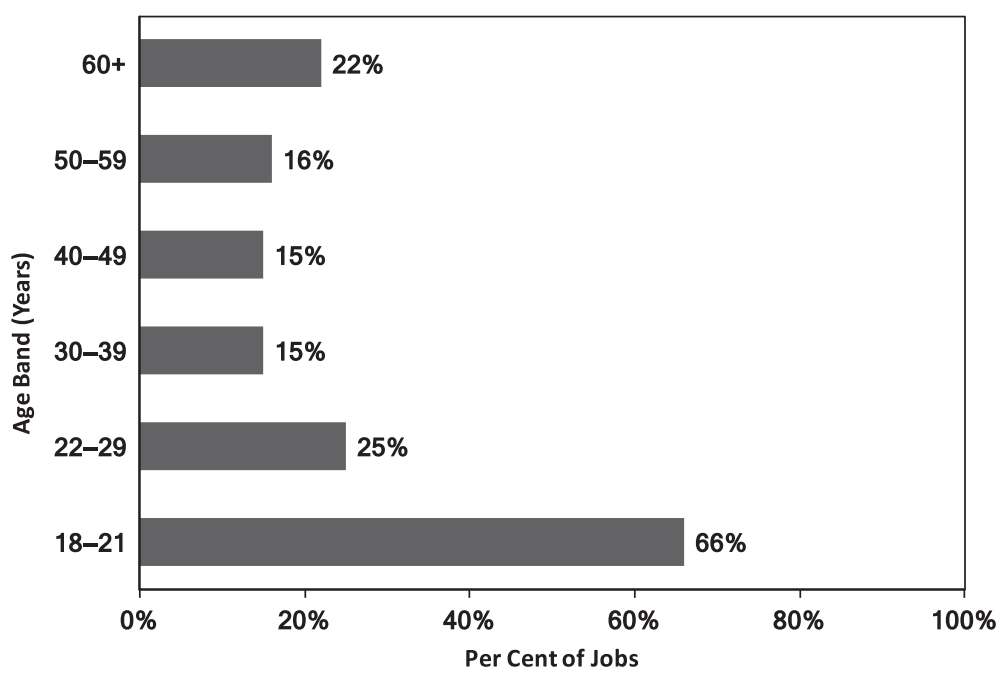

Fig. 5.2 Estimated percentage of jobs paying less than the voluntary living wage, by employee age, England, Scotland and Wales, 2017. (Source: IHS Markit (2017, Table 3.6.1, p. 11))

These data indicate a major policy challenge within a wellbeing economics framework. Even with social security support, more than one in seven employed people aged between 30 and 59 are in jobs that do not pay a wage deemed high enough to provide families with the essentials of life. The proportion is higher for younger and older age groups. In other words, employment is not sufficient to guarantee that a person can afford to purchase the market goods and services needed to create a level of wellbeing judged reasonable by the standards of the day.

Further, there is a strong gender disparity in this experience: 26 per cent of employed females are paid less than the voluntary living wage, compared to 16 per cent of employed males (idem, p. 9). This difference is contrary to Proposition 8 that men and women can have equal capabilities for wellbeing. More than one in four women in paid work are not earning the real living wage; this must restrict capabilities for creating wellbeing for themselves and their families.

\section{Economic Capital}

Economic capital encompasses physical capital and financial capital. Physical capital refers to long-lasting human-made material assets such as buildings, factories, roads, vehicles, machinery, equipment and the like. Financial capital 
refers to nominal assets such as equities, shares, securities, bonds, debentures, bank deposits and cash.

Physical and financial capitals are closely connected. A firm includes physical capital on the assets side of its balance sheet, funded by financial capital on the liabilities side. A household with savings distributes its wealth between physical capital (such as home ownership) and a portfolio of financial capital. The financial assets are backed by physical and other types of capital, whose profit streams underpin the portfolio's economic value.

Economic policy pays close attention to investment in new physical capital (OECD 2015). This is justified by its importance in the national economy. In the United Kingdom, for example, this expenditure was valued in 2016 at $£ 260$ billion, which was 13.5 per cent of that year's gross domestic product. ${ }^{6}$ As Keynes (1936) first explained, the amount of investment expenditure influences a nation's level of economic activity, so that a large drop in investment can push the economy into recession. In the medium term, the neoclassical growth model shows that a country tends to have a higher value of output produced per hour of work if a greater share of its output is devoted to physical capital investment (see Chap. 1).

A further reason for close attention to physical capital investment is that firms and households rely on the public sector to maintain and expand core infrastructure such as transport networks and essential utilities such as water and sewer networks (Aschauer 1989; Munnell 1992; Gramlich 1994; Pereira and Andraz 2013). These networks and utilities are essential for promoting wellbeing, to the extent that the UK Government has created the Infrastructure and Projects Authority whose purpose is "to continuously improve the way infrastructure and major projects are delivered in order to support government priorities and improve people's lives" (IPA 2017, p. 1).

Experiences over the last two decades indicate some deep-seated problems in the role of economic capital in promoting wellbeing. First, and arguably the most pressing issue, current patterns of physical capital investment and technological development are having cumulative and potentially irreversible impacts on the environment (OECD 2011, p. 10).

Recognising this challenge, the OECD recommends strategies to foster green growth, including: carbon emission pricing to reflect its full environmental and economic costs, temporary support for new technologies with lower environmental impacts, reduced barriers to the development and diffusion of green technologies globally, and investment in public network infrastructure that supports next-generation technologies (idem, p. 12). The UK Government's Clean Growth Strategy (HM Government 2017) is an example of an integrated public strategy that aims to support investment in innovation for clean growth. 
A second issue from recent experience can be seen in Fig. 5.3, which depicts the United Kingdom's physical capital investment from 2001 to 2016. The sharp fall in physical capital investment during the Global Financial Crisis of 2007-2008 is clearly visible. Investment fell from $£ 250$ billion in 2007 to $£ 196$ billion in 2009 , a reduction of 21.6 per cent. It returned to its 2007 value only in 2015. Fluctuations of this size are a serious challenge to policy goals of maintaining stable and full employment.

That episode also illustrates the close connection between physical and financial capital, since it is universally agreed that the origins of the crisis lay in financial markets. The Financial Crisis Inquiry Commission was appointed by the US Government to examine what led to the greatest financial crisis since the Great Depression. It reported as follows (Financial Crisis Inquiry Commission 2011, p. xvi):

While the vulnerabilities that created the potential for crisis were years in the making, it was the collapse of the housing bubble - fuelled by low interest rates, easy and available credit, scant regulation, and toxic mortgages - that was the spark that ignited a string of events, which led to a full-blown crisis in the fall of 2008. ...

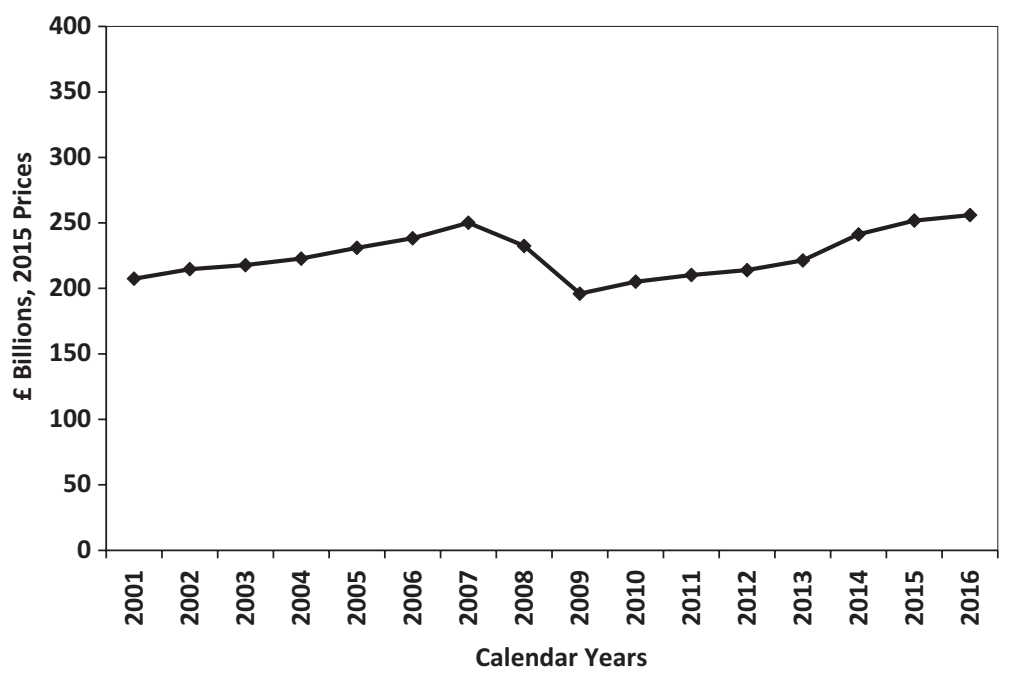

Fig. 5.3 Annual gross fixed capital formation, excluding cultivated assets and intellectual property products, United Kingdom, 2001 to 2016. (Note: The series is the chained volume measure (CVM), which removes the impact of price changes; the values are presented at 2015 prices. Source: Calculated from ONS (2017a)) 
When the bubble burst, hundreds of billions of dollars in losses in mortgages and mortgage-related securities shook markets as well as financial institutions that had significant exposures to those mortgages and had borrowed heavily against them.

Thomas Piketty (2013) has published long-term data from different countries to demonstrate that income inequality has generally been increasing in recent decades. He hypothesises that this trend is amplified by financial returns to the ownership of capital exceeding the rate of economic growth. ${ }^{7}$ This means income from capital ownership typically grows faster than income from wages, with straightforward consequences for concentration of wealth and power (idem, p. 26):

Under such conditions, it is almost inevitable that inherited wealth will dominate wealth amassed from a lifetime's labor by a wide margin, and the concentration of capital will attain extremely high levels - levels potentially incompatible with the meritocratic values and principles of social justice fundamental to modern democratic societies.

Thus, economic capital is important for wellbeing, but there are issues that must be addressed for it to contribute to its full potential. This is summarised in Proposition 15.

Proposition 15 Investment in physical capital and the growth of financial capital can contribute to enhanced wellbeing, but recent patterns of economic development are also associated with cumulative environmental damage, episodes of financial instability and greater concentration of wealth.

\section{Conclusion}

The market economy supports substantial expansion of human wellbeing, yet markets do not always work well. Firms maintain specialist capabilities for supplying market goods and services that enhance wellbeing; yet firms also offer a large number of jobs paying less than the real living wage. Growth in economic capital has increased material living standards for billions of people; yet recent economic development is also associated with cumulative environmental damage, episodes of financial instability and greater concentration of wealth.

Chapter 3 concluded with the question: How can it be culturally acceptable for such high levels of parental inequality, intimate violence, poor housing and 
child poverty to be allowed to persist? This chapter has highlighted a key causal mechanism of these outcomes. More than one in seven employed persons aged between 30 and 59 are in employment that does not pay a living wage sufficient to support family life, with a strong gender bias. This must limit capabilities for wellbeing. It is a glaring example of how economic policies that do not pay attention to how the economy is growing (in this case, through the creation of large numbers of low-wage jobs) can harm personal and social wellbeing.

The book now turns to how local and central governments can contribute to enhanced wellbeing.

\section{Notes}

1. Specialisation may also contribute to workers' experience of powerlessness, meaninglessness, normlessness, isolation and self-estrangement, expressed in the concept of "alienation" (Seeman 1959; Neal and Rettig 1963).

2. See Teece (2017a, b) for recent overviews. Kay (1993) also emphasises the importance of a firm's distinctive capabilities, especially its architecture, reputation, innovation and strategic assets.

3. There are also social enterprises operating in the market economy with explicit commitments to social purposes (Besley and Ghatak 2017; Social Enterprise UK 2017).

4. See Feather (1990), Clark and Oswald (1994), Winkelmann and Winkelmann (1998), Clark (2003), Dockery (2005), Winkelmann (2009, 2014), Grün et al. (2010), Knabe et al. (2010), Brown et al. (2012), Gielen and van Ours (2014), Helliwell and Huang (2014), Hetschko et al. (2014), Wulfgramm (2014) and De Neve and Ward (2017).

5. Oswald et al. (2015) provide experimental evidence of a possible connection in the reverse direction, suggesting worker happiness might contribute to labour productivity.

6. This is gross fixed capital formation, excluding investment in intellectual property products and in cultivated assets, taken from ONS (2017a). Intellectual property products are part of knowledge capital, and cultivated assets (livestock for breeding) are part of natural capital; see ONS (2017b).

7. Piketty's empirical findings are generally accepted by economists, but not his theoretical explanation; see, for example, Summers (2014), Acemoglu and Robinson (2015), Auerbach and Hassett (2015), Blume and Durlauf (2015), Krusell and Smith (2015) and Mankiw (2015). Piketty (2015) addresses some of these criticisms. 


\section{References}

Acemoglu, Daron, and James A. Robinson. 2015. The Rise and Decline of General Laws of Capitalism. Journal of Economic Perspectives 29 (1): 3-28.

Arulampalam, Wiji. 2001. Is Unemployment Really Scarring? Effects of Unemployment Experiences on Wages. Economic Journal 111 (475): 585-606.

Arrow, Kenneth J. 1951. An Extension of the Basic Theorems of Classical Welfare Economics. In Proceedings of the Second Berkeley Symposium on Mathematical Statistics and Probability, ed. Jerzy Neyman, 507-532. Berkeley: University of California Press.

Aschauer, David Alan. 1989. Is Public Expenditure Productive? Journal of Monetary Economics 23 (2): 177-200.

Auerbach, Alan J., and Kevin Hassett. 2015. Capital Taxation in the Twenty-First Century. American Economic Review 105 (5): 38-42.

Besley, Timothy, and Maitreesh Ghatak. 2017. Profit with Purpose? A Theory of Social Enterprise. American Economic Journal: Economic Policy 9 (3): 19-58.

Blume, Lawrence E., and Steven N. Durlauf. 2015. Capital in the Twenty-First Century: A Review Essay. Journal of Political Economy 123 (4): 749-777.

Brown, Denise, Julie Woolf, and Conal Smith. 2012. An Empirical Investigation into the Determinants of Life Satisfaction in New Zealand. New Zealand Economic Papers 46 (3): 239-251.

Caswell, Julie A., and Eliza M. Mojduszka. 1996. Using Informational Labeling to Influence the Market for Quality in Food Products. American Journal of Agricultural Economics 78 (5): 1248-1253.

Chamberlin, Edward H. 1933. The Theory of Monopolistic Competition: A Re-orientation of the Theory of Value. Cambridge, MA: Harvard University Press.

Clark, Andrew E. 2003. Unemployment as a Social Norm: Psychological Evidence from Panel Data. Journal of Labor Economics 21 (2): 323-351.

Clark, Andrew E., Yannis Georgellis, and Peter Sanfey. 2001. Scarring: The Psychological Impact of Past Unemployment. Economica 68 (270): 221-241.

Clark, Andrew E., and Andrew J. Oswald. 1994. Unhappiness and Unemployment. Economic Journal 104 (42): 648-659.

Coase, Ronald H. 1937. The Nature of the Firm. Economica 4 (16): 386-405.

Crotty, James. 2009. Structural Causes of the Global Financial Crisis: A Critical Assessment of the 'New Financial Architecture'. Cambridge Journal of Economics 33 (4): 563-580.

Darby, Michael R., and Edi Karni. 1973. Free Competition and the Optimal Amount of Fraud. Journal of Law and Economics 16 (1): 67-88.

De Neve, Jan-Emmanuel, and George Ward. 2017. Happiness at Work. In World Happiness Report 2017, ed. John Helliwell, Richard Layard, and Jeffrey Sachs, 144-177. New York: Sustainable Development Solutions Network. 
Debreu, Gérard. 1959. Theory of Value: An Axiomatic Analysis of Economic Equilibrium. New York: John Wiley.

Dockery, Alfred M. 2005. The Happiness of Young Australians: Empirical Evidence on the Role of Labour Market Experience. Economic Record 81 (255): 322-335.

Feather, Norman T. 1990. The Psychological Impact of Unemployment. New York: Springer-Verlag.

Financial Crisis Inquiry Commission. 2011. The Financial Crisis Inquiry Report: The Final Report of the National Commission on the Causes of the Financial and Economic Crisis in the United States, Including Dissenting Views. New York: Cosmo Reports.

Galbraith, John Kenneth. 1952. American Capitalism - The Concept of Countervailing Power. Boston MA: Houghton Mifflin.

Gielen, Anne C., and Jan C. van Ours. 2014. Unhappiness and Job Finding. Economica 81 (323): 544-565.

Gramlich, Edward M. 1994. Infrastructure Investment: A Review Essay. Journal of Economic Literature 32 (4): 1176-1196.

Gregg, Paul. 2001. The Impact of Youth Unemployment on Adult Unemployment in the NCDS. Economic Journal 111 (475): 626-653.

Gregory, Mary, and Robert Jukes. 2001. Unemployment and Subsequent Earnings: Estimating Scarring among British Men 1984-94. Economic Journal 111 (475): 607-625.

GRI. 2016. Empowering Sustainable Decisions: GRI's Annual Report 2015-2016. Global Reporting Initiative (GRI). https://www.globalreporting.org/information/about-gri/ Pages/GRIs-own-reports.aspx. Accessed 4 Oct 2017.

Grün, Carola, Wolfgang Hauser, and Thomas Rhein. 2010. Is Any Job Better than No Job? Life Satisfaction and Re-employment. Journal of Labour Research 31 (3): 285-306.

Hart, Oliver. 2017. Incomplete Contracts and Control. American Economic Review 107 (7): 1731-1752.

Haucap, Justus, and Ulrich Heimeshoff. 2013. Google, Facebook, Amazon, eBay: Is the Internet Driving Competition or Market Monopolization? International Economics and Economic Policy 11 (1-2): 49-61.

Hayek, Friedrich. 1945. The Use of Knowledge in Society. American Economic Review 35 (4): 519-530.

Helliwell, John F., and Haifang Huang. 2014. New Measures of the Costs of Unemployment: Evidence from the Subjective Well-being of 3.3 Million Americans. Economic Inquiry 52 (4): 1485-1502.

Hetschko, Clemens, Andreas Knabe, and Ronnie Schöb. 2014. Changing Identity: Retiring from Unemployment. Economic Journal 124 (575): 149-166.

Hicks, John R. 1939. The Foundations of Welfare Economics. Economic Journal 49 (196): 696-712.

Hirsch, Donald, and Rhys Moore. 2011. The Living Wage in the United Kingdom: Building on Success. London: Living Wage Foundation. 
HM Government. 2017. The Clean Growth Strategy: Leading the Way to a Low Carbon Future. London: Department for Business, Energy \& Industrial Strategy.

IHS Markit. 2017. Living Wage Research for KPMG. Henley on Thames: IHS Markit Ltd.

IPA. 2017. Annual Report on Major Projects 2016-17. London: Infrastructure and Projects Authority.

Jackson, Tim. 2017. Prosperity without Growth: Foundations for the Economy of Tomorrow. 2nd ed. Abingdon/New York: Routledge.

Kay, John. 1993. Foundations of Corporate Success: How Business Strategies Add Value. Oxford: Oxford University Press.

Keynes, John Maynard. 1936. The General Theory of Employment, Interest and Money. London: Macmillan.

Knabe, Andreas, Steffen Rätzel, Ronnie Schöb, and Joachim Weimann. 2010. Dissatisfied with Life but Having a Good Day: Time-use and Well-being of the Unemployed. Economic Journal 120 (547): 867-889.

Krusell, Per, and Anthony A. Smith, Jr. 2015. Is Piketty's "Second Law of Capitalism" Fundamental? Journal of Political Economy 123 (4): 725-748.

Living Wage Foundation. 2017. What is the Real Living Wage. https://www.livingwage. org.uk/what-real-living-wage. Webpage accessed 30 Oct 2017.

Mankiw, N. Gregory. 2015. Yes, r > g. So What? American Economic Review 105 (5): 43-47.

Marmot, Michael. 2010. Fair Society, Healthy Lives: A Strategic Review of Health Inequalities in England Post-2010. London: The Marmot Review.

Maslow, Abraham H. 1943. A Theory of Human Motivation. Psychological Review 50 (4): 370-396.

-1954. Motivation and Personality. New York: Harper.

McMillan, John. 2002. Reinventing the Bazaar: A Natural History of Markets. New York/ London: W. W. Norton.

Mullainathan, Sendhil, and Eldar Shafir. 2013. Scarcity: Why Having Too Little Means So Much. New York: Times Books, 2013.

Munnell, Alicia H. 1992. Policy Watch: Infrastructure Investment and Economic Growth. Journal of Economic Perspectives 6 (4): 189-198.

Neal, Arthur G., and Salomon Rettig. 1963. Dimensions of Alienation among Manual and Non-Manual Workers. American Sociological Review 28 (4): 599-608.

OECD. 2011. Towards Green Growth. Paris: OECD Publishing https://doi. org/10.1787/9789264111318-en.

- 2015. Policy Framework for Investment, 2015 Edition. Paris: OECD Publishing https://doi.org/10.1787/9789264208667-en.

ONS. 2017a. Annual Gross Fixed Capital Formation by Industry and Asset. Database released 29 September, Office for National Statistics.

2017b. A Short Guide to Gross Fixed Capital Formation and Business Investment. Article released 25 May, Office for National Statistics. 
Oswald, Andrew J., Eugenio Proto, and Daniel Sgroi. 2015. Happiness and Productivity. Journal of Labor Economics 33 (4): 789-822.

Pereira, Alfredo M., and Jorge M. Andraz. 2013. On the Economic Effects of Public Infrastructure Investment: A Survey of the International Evidence. Journal of Economic Development 38 (4): 1-37.

Pareto, Vilfredo. 1906. Manuale di Economia Politica. Milan: Societa Editrice Libraria.

Piketty, Thomas. 2013. Le capital au XXI siècle. Paris: Éditions du Seuil. Translated by Arthur Goldhammer and published in English as Capital in the Twenty-First Century. Cambridge, MA: Belknap Press, 2014.

- 2015. About Capital in the Twenty-First Century. American Economic Review 105 (5): 48-53.

Polanyi, Karl. 1944. The Great Transformation: The Political and Economic Origins of Our Time. New York: Farrar \& Rinehart.

PwC. 2013. Measuring and Managing Total Impact: A New Language for Business Decisions. PwC Network, downloaded 3 October 2017 at www.pwc.com/totalimpact.

Rawls, John. 1971. A Theory of Justice. Cambridge, MA: Harvard University Press.

Rhodes, Chris. 2016. Business Statistics. Briefing Paper Number 06152. London: House of Commons Library.

Robinson, Joan. 1933. The Economics of Imperfect Competition. London: Macmillan.

Sandel, Michael. 2012. What Money Can't Buy: The Moral Limits of Markets. New York: Farrar, Straus and Giroux.

Schumpeter, Joseph. 1943. Capitalism, Socialism and Democracy. London: George Allen $\&$ Unwin.

Seely, Antony. 2016. The UK Competition Regime. Briefing Paper Number 04814. London: House of Commons Library.

Seeman, Melvin. 1959. On the Meaning of Alienation. American Sociological Review 24 (6): 783-791.

Sen, Amartya. 2009. The Idea of Justice. Cambridge, MA: Harvard University Press.

Shah, Anuj K., Sendhil Mullainathan, and Eldar Shafir. 2012. Some Consequences of Having Too Little. Science 338 (6107): 682-685.

Smith, Adam. 1776. An Enquiry into the Nature and Causes of the Wealth of Nations, 2 vols., University Paperbacks edition, ed. by Edwin Cannan. London: Methuen.

Social Enterprise UK. 2017. The Future of Business: State of Social Enterprise Survey 2017. London: Social Enterprise UK.

Summers, Lawrence H. 2014. The Inequality Puzzle. Democracy 33 (Summer). https:// democracyjournal.org/magazine/33/the-inequality-puzzle/. Accessed 6 Feb 2017.

Teece, David J. 1982. Towards an Economic Theory of the Multiproduct Firm. Journal of Economic Behavior \& Organization 3 (1): 39-63.

- 2017a. Towards a Capability Theory of (Innovating) Firms: Implications for Management and Policy. Cambridge Journal of Economics 41 (3): 693-720. 
- 2017b. A Capability Theory of the Firm: An Economics and (Strategic) Management Perspective. New Zealand Economic Papers, forthcoming, https://doi.org/ 10.1080/00779954.2017.1371208.

Teece, David J., Gary Pisano, and Amy Shuen. 1997. Dynamic Capabilities and Strategic Management. Strategic Management Journal 18 (7): 509-533.

Williamson, Oliver E. 2010. Transaction Cost Economics: The Natural Progression. American Economic Review 100 (3): 673-690.

Winkelmann, Liliana, and Rainer Winkelmann. 1998. Why are the Unemployed so Unhappy? Evidence from Panel Data. Economica 65 (257): 1-15.

Winkelmann, Rainer. 2009. Unemployment, Social Capital, and Subjective Well-Being. Journal of Happiness Studies 10 (4): 421-430.

. 2014. Unemployment and Happiness. IZA World of Labor 94. https://doi. org/10.15185/izawol.94.

Wulfgramm, Melike. 2014. Life Satisfaction Effects of Unemployment in Europe: The Moderating Influence of Labour Market Policy. Journal of European Social Policy 24 (3): 258-272.

Open Access This chapter is licensed under the terms of the Creative Commons Attribution 4.0 International License (http://creativecommons.org/licenses/by/4.0/), which permits use, sharing, adaptation, distribution and reproduction in any medium or format, as long as you give appropriate credit to the original author(s) and the source, provide a link to the Creative Commons license and indicate if changes were made.

The images or other third party material in this chapter are included in the chapter's Creative Commons license, unless indicated otherwise in a credit line to the material. If material is not included in the chapter's Creative Commons license and your intended use is not permitted by statutory regulation or exceeds the permitted use, you will need to obtain permission directly from the copyright holder. 